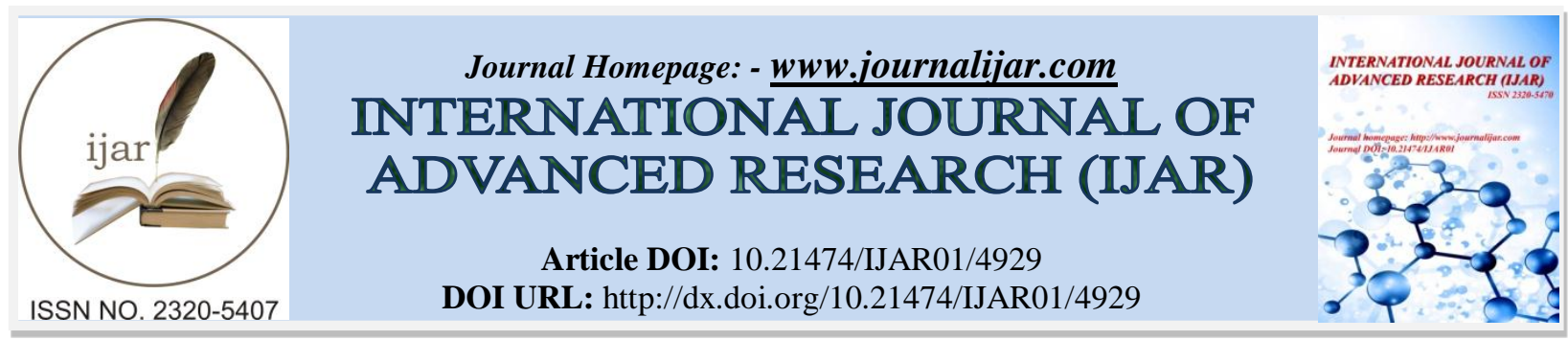

RESEARCH ARTICLE

\title{
THE EFFECT OF TRANSFORMATIONAL LEADERSHIP, CAPABILITY, AND COMMITMENT ON MOVATION OF SOLDIERS AND THE IMPACT OF MOTIVATION ON PERFORMANCE OF SOLDIERS AT THE COMMAND UNIT OF MILITARY DISTRICT 0807 TULUNGAGUNG.
}

\author{
Brantas Suharyo $\mathbf{G}^{\mathbf{1}}$, Zaenal Fanani ${ }^{2}$ and Mohammad Soleh ${ }^{2}$. \\ 1. Students Magister Program of National Defense of Postgraduate Program Brawijaya University. \\ 2. Lecturer Magister Program of National Defense of Postgraduate Program of Brawijaya University.
}

\section{Manuscript Info}

Manuscript History

Received: 23 May 2017

Final Accepted: 25 June 2017

Published: July 2017

\section{Abstract}

Leadership is a central point of success because leadership can multiply the possibility of success of military units. Successful leadership in military environment is measured using four aspects, such as morality, discipline, loyalty and competence. Each aspect has certain parameter and method to measure leadership success across different aspects, including morality and discipline aspects. Indonesia National Army (TNI), especially Ground Force, has attempted to excavate, to adopt, to explore, and to apply, as well as to develop the proper sciences and theories of leadership. All of these are important because it helps TNI to identify leaders based on their strata and rank in pursuant with President Decree No.10/2010 about Organizational Structure of TNI.

The objective of research includes to understand the effect of transformational leadership, capability, and commitment on motivation; to examine the impact of motivation on performance of members at the Command Unit of Military District 0807 Tulungagung; and to investigate the dominant effect that influences motivation and performance of soldiers at the Command Unit of Military District 0807 Tulungagung. Research location is the Command Unit of Military District 0807 Tulungagung addressed at MT. Haryono Road No.37-38 Tulungagung. Meanwhile, time of research starts from 22 January 2017 to 02 March 2017, in which this research will last for 3 months. The sample of research is 120 soldiers. Data analysis technique uses Structural Equation Modeling (SEM) with Software WarpPLS 5.0.

Result of research indicates that the commitment of soldiers at the Command Unit of Military District 0807 Tulungagung has an effect of $50 \%$ to membership motivation, while the motivation of soldiers at the Command Unit of Military District 0807 Tulungagung remains influential for $75.7 \%$ to soldiers' performance. Normative commitment has the highest load, and provides a positive and very significant effect on creating a responsibility for soldiers to establish a motivation. Soldiers' motivation has the highest load which then gives positive and very significant effect on their authority of responsibility. Periodic evaluation on soldiers' motivation and performance must be 
done once in 3 months to recognize the parameters for successful effect of leadership transformation, capability, and commitment on soldiers' motivation and performance.

Copy Right, IJAR, 2017,. All rights reserved.

\section{Introduction:-}

Background:-

Leadership refers to a central point of success because leadership can multiply the possibility of success of military units. Successful leadership in military environment can be measured with four aspects, such as morality, discipline, loyalty, and competence. Each aspect has certain parameter and method to measure the success of leadership across one aspect to another, among others including morality and discipline aspects.

Indonesia National Force (TNI), especially Army Force, is already working on activities to excavate, to adopt, to explore, and to apply, as well as to develop the proper sciences and theories of leadership. These activities would help TNI to identify leaders based on their strata and rank in pursuant with President Decree No.10/2010 about Organizational Structure of TNI. It may improve leadership quality of military officers who graduate from Academy of TNI, especially Military Academy. It is expected that by effective and efficient field leadership (face-to-face leadership), the lesson of leadership can be transferred into subordinate leaders to produce sustainable leadership.

Capability is a set of skill and learning by which the organization will coordinate its functional activities. A leader with high capability generally has a reliable information about what organization must need in order to survive. The interest and demand of organization may then set a direction for the members.

Successful management of organization is determined by successful management of human resource. The commitment of employees to the organization where they work will determine the achievement of organization toward the goal. In employment world, employees' commitment to organization is a very important issue, and some organizations are dauntless enough to require commitment as one condition to hold certain rank/position offered in vacancy. Unfortunately, entrepreneurs or their employees do not understand what commitment means. This understanding is very important to create a conducive work, and therefore, it helps to manage organization efficiently and effectively.

Human as organizational member is quite affected by different personality attributes, especially when they are at work. These attributes include character, attitude, value, desire and interest, and all of these will influence leadership style and performance. Making a harmony between individual values and company values would require a process called "socialization". It helps new entrants to feel accepted by others as a trusted person and have freedom to profess their own values. It gives them a self-confidence to work successfully because they understand the system, not only system related with their works, but also the rules.

The capability in this paper is about the professionalism of soldiers. This professionalism covers military skills and competences, and within it, there is technique, tactic and strategy. The essence of military professionalism is to master military standard capacity, and to develop the field-work. For TNI, improving professionalism is primary commitment. In general, reformation on TNI is aimed to create the professional posture of TNI soldiers.

\section{Problem Formulation:-}

Based on this background, some problems are formulated relevant to this research:

1. How is the effect of transformational leadership, capability and commitment on motivation and also the impact of motivation on performance of soldiers at the Command Unit of Military District 0807 Tulungagung?

2. What model is with the most dominant effect on motivation and performance of soldiers at the Command Unit of Military District 0807 Tulungagung?

\section{Objective of Research:-}

By taking account the formulated problems above, the objectives of research are explained as following:-

1. To understand the effect of transformational leadership, capability and commitment on motivation and also the impact of motivation on performance of soldiers at the Command Unit of Military District 0807 Tulungagung. 
2. To recognize the model with the most dominant effect on motivation and performance of soldiers at the Command Unit of Military District 0807 Tulungagung.

\section{Method Of Research:-}

Time and Location of Research

The location of research is the Command Unit of Military District 0807 Tulungagung addressed at MT. Haryono Road No.37-38 Tulungagung. Research starts from 22 January 2017 to 02 March 2017, or lasting for 3 months.

\section{Method of Research:-}

Research uses analytical-descriptive method with quantitative approach. This method involves Structural Equation Modeling (SEM) with Software WarpPLS 5.0. It is used to obtain clear and detail description about the observed researches and phenomena.

Type of Research:-

Research type is survey, where the sample is taken from a population by using questionnaire as data collection instrument (Singarimbun, 1995).

\section{Sampling Technique:-}

Sampling technique is total sampling because the sample includes all members or soldiers at the Command Unit of Military District 0807 Tulungagung. There are 120 persons as respondent representative. The reason behind this number is that it is a result from minimally 5 times of total items in the questionnaire (Malhotra, 1995).

\section{Data Analysis Technique:-}

Validity and Reliability Tests are performed with SEM supported by Software WarpPLS.5. Structural Equation Modeling (SEM) can directly provide explanation about validity and reliability tests. The validity of question is an indicator that measures certain latent variable, and the validity is known by testing whether all loads are significant $(\mathrm{p}<0.05)$ by condition of $\mathrm{t}$-test greater than 1.96 . The reliability of an indicator can be known by calculating composite reliability or construct reliability in the following equation (Ghozali and Fuad, 2005):

$\rho=((\Sigma \lambda) 2) /[(\Sigma \lambda) 2+\Sigma(\theta)]$

Where:

$\rho=$ composite reliability

$\lambda=$ loading indicator

$\theta=$ error variance indicator

\section{Result And Discussion:-}

Structural Model of The Effect of Transformational Leadership, Capability, and Commitment on Motivation and The Impact of Motivation on Performance of Soldiers at the Command Unit of Military District 0807 Tulungagung

Structural model is using Partial Least Square. It is a construct model aimed to develop a theory that would be useful to modify the existing model. PLS-SEM is aimed to attest predictive relationship across the constructs by examining whether there is a relationship or an effect between these constructs. The consequence from the use of PLS-SEM is that it is conducted without strong theoretical base by disregarding parameteric and non-parameteric assumptions. The predicted model precision is observed from coefficient of determination (R-Square). Therefore, PLS-SEM is very appropriate in a research aiming to develop a theory. In SEM method, some variables are considered and called as predictor variable, response variable, and mediator variable. Mediator variable is a connecting variable between predictor variable and response variable. Mediator variable can change into response variable if it is affected by predictor variable, and also can become predictor variable if it influences response variable.

Mediator variable is called as intervening variable, where theoretically, it influences the observed phenomena (endogenous variable). This effect must be inferred through the effect of relationship betwen exogenous variable and its phenomena. If exogenous variable is not anymore influential to endogenous variable after controlling mediator variable, then there will be perfect or complete mediation. If the effect of exogenous variable on endogenous variable is decreasing, but it still differs from 0 after controlling mediator variable, thus, partial mediation exists (Jogiyanto and Abdillah, 2009). 
The author uses WarpPLS as a tool for statistic data processing. It is used to understand the effect of complexity involving constructs and recursive indicators. Therefore, the approach of variance is used until the load of each item can be seen. The author expects that this approach would be helpful to understand the loading value that can represent latent variable as the predictor that influences response variable. The following is a structural model describing the Effect of Transformational Leadership, Capability, and Commitment on Movation and The Impact of Motivation on The Performance of Members in Command Unit of Military District 0807 Tulungagung.

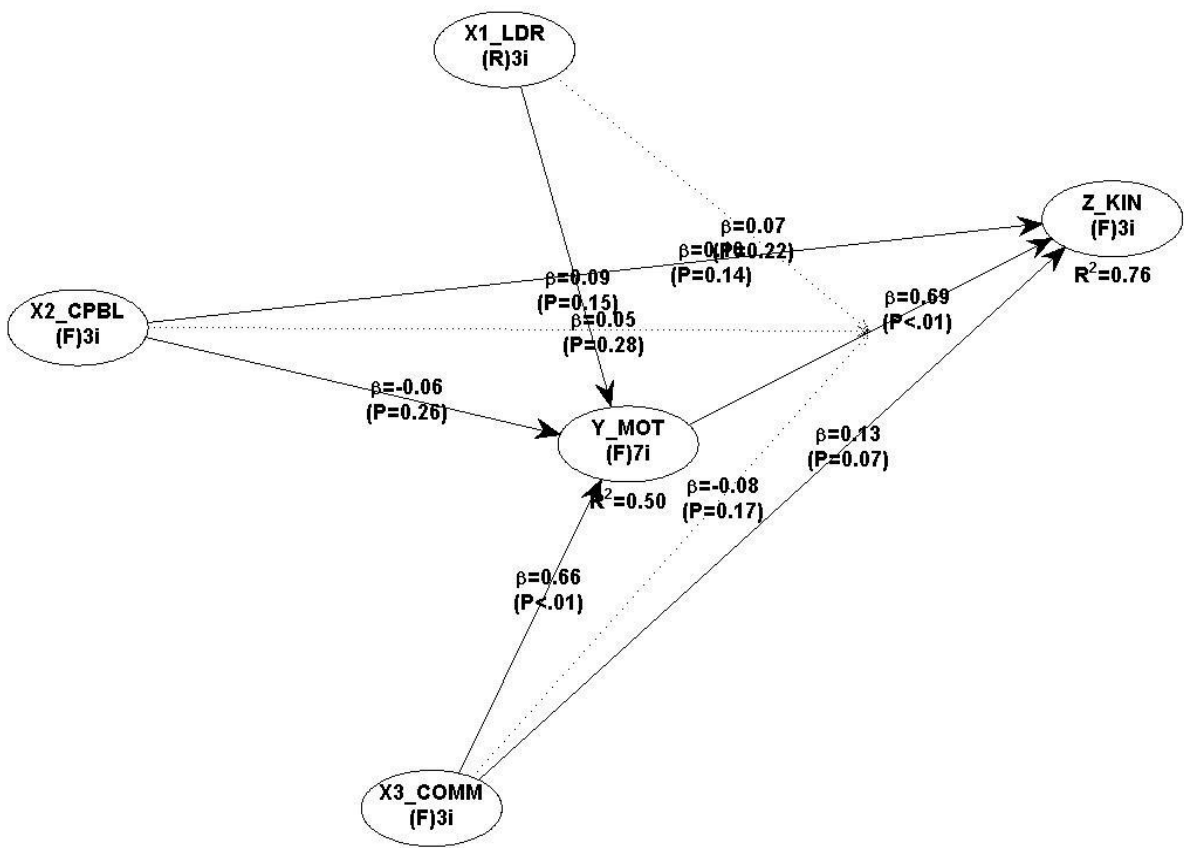

Figure 1:- Path Interpretation.

\section{Implication of Result of Research:-}

Data analysis has used WarpPLS.5, and the result indicates that the commitment of soldiers at the Command Unit of Military District 0807 Tulungagung has effect rate of $50 \%$ on their motivation. Beta coefficient rate of this commitment is 0.659 as shown by normative commitment. It means that the increase of normative commitment for one (1) unit will increase the motivation of soldiers at the Command Unit of Military District 0807 Tulungagung for 0.659. The latent variable of normative commitment has the highest load. This load means that this commitment has a positive and very significant effect on creating a responsibility for soldiers to establish a motivation. The effect rate of normative commitment on soldiers' responsibility is counted for $50 \%$.

Result of data analysis with WarpPSL.5 shows that the motivation of soldiers at the Command Unit of Military District 0807 Tulungagung has effect rate of $75.7 \%$ on their performance. Beta coefficient rate of soldiers' motivation is 0.690 . The increasing motivation of soldiers for 1 unit would increase the performance of soldiers at the Command Unit of Military District 0807 Tulungagung for 0.690. The latent variable of soldiers' motivation has the highest load, and it has a positive and very significant effect on creating a responsibility for soldiers to establish a motivation, and this motivation then gives positive and very significant effect on their authority of responsibility. The capability of soldiers to take responsibility in any polemics at the Command Unit of Military District 0807 Tulungagung has an effect on their authority of responsibility for $75.7 \%$.

\section{Conclusion and Suggestion:-}

In regard to the result of research and discussion, then conclusions and suggestions can be explained as following:

\section{Conclusion:-}

1. The commitment of soldiers at the Command Unit of Military District 0807 Tulungagung has effect rate of 50\% on their motivation. Moreover, the motivation of soldiers at the Command Unit of Military District 0807 Tulungagung has effect rate of $75.7 \%$ on their performance. 
2. Normative commitment has the highest load, and provides a positive and very significant effect on creating a responsibility for soldiers to establish a motivation. Soldiers' motivation has the highest load which then gives positive and very significant effect on their authority of responsibility.

\section{Suggestions:-}

1. Soldiers' motivation and performance should be subjected to periodic evaluation once in 3 months to acknowledge the parameters for successful effect of leadership transformation, capability, and commitment on soldiers' motivation and performance.

2. The responsibility behavior of soldiers for their superior or for the nation must be developed and fostered to empower the unity and coalescence of the nation.

\section{References:-}

1. Bob Waworuntu, 2003. Determinan Kepemimpinan. Makara, Sosial Humaniora, Vol. 7, No. 2, Desember 2003

2. Ivancevich, John M. 2002. Human Resource Management (8th.ed). Richard D. Irwin, Inc, USA

3. Mulyono, 2013. Pengaruh Kepemimpinan, Komunikasi, Motivasi, Pengembangan Karir, Dan Promosi Jabatan Terhadap Kinerja Pegawai Kantor Sekretariat Daerah Kabupaten Sukoharjo.

4. Mujiasih, Endah dan Sutrisno Hadi, 2012. "Persepsi Gaya Kepemimpinan Transformasional". Jurnal Wacana, Vol.1. Nomor 08 Tahun 2012.

5. Nawawi, Hadari, 2001. Manajemen Sumber Daya Manusia: Untuk Bisnis Kompetitif. Cetakan Keempat. Penerbit Gajdah Mada University Press. Yogyakarta

6. Satryo, 1997, Pengaruh Kepemimpinan Terhadap Kepuasan Kerja Pegawai Pada Dinas Pendapatan Propinsi Jawa Timur Cabang Malang, Thesis Pada Program Pasca Sarjana Universitas Airlangga Surabaya.

7. Siagian, Sondang P, 1995, Manajemen Sumber Daya Manusia, Bumi Aksara, Jakarta.

8. Sutarto, 1989, Dasar-Dasar Kepemimpinan Administrasi, UGM Press, Yogyakarta.

9. Sudarto, Dawam \& Herman Matondang, (2002), Materi Pokok Pengelolaan Keuangan Negara, BPLK, Jakarta

10. Singarimbun, M dan S. Effendi, 1989, Metode Penelitian Survey, LP3ES, Jakarta.

11. Widyatmini dan Luqman Hakim, 2008. Hubungan Kepemimpinan, Kompensasi Dan Kompetensi Terhadap Kinerja Pegawai Dinas Kesehatan Kota Depok. Jurnal Ekonomi Bisnis No. 2 Vol. 13, Agustus 2008. 